\title{
用以塑造视野的影像散文 \\ THE VIDEO ESSAY AS GEOMORPHIC TOOL
}

乌苏拉 · 比曼 艺术家、影像散文创作者

Ursula BIEMANN Artist and Video Essayist

Röntgenstrasse 48, CH-8005 Zurich, Switzerland

ursula@geobodies.org

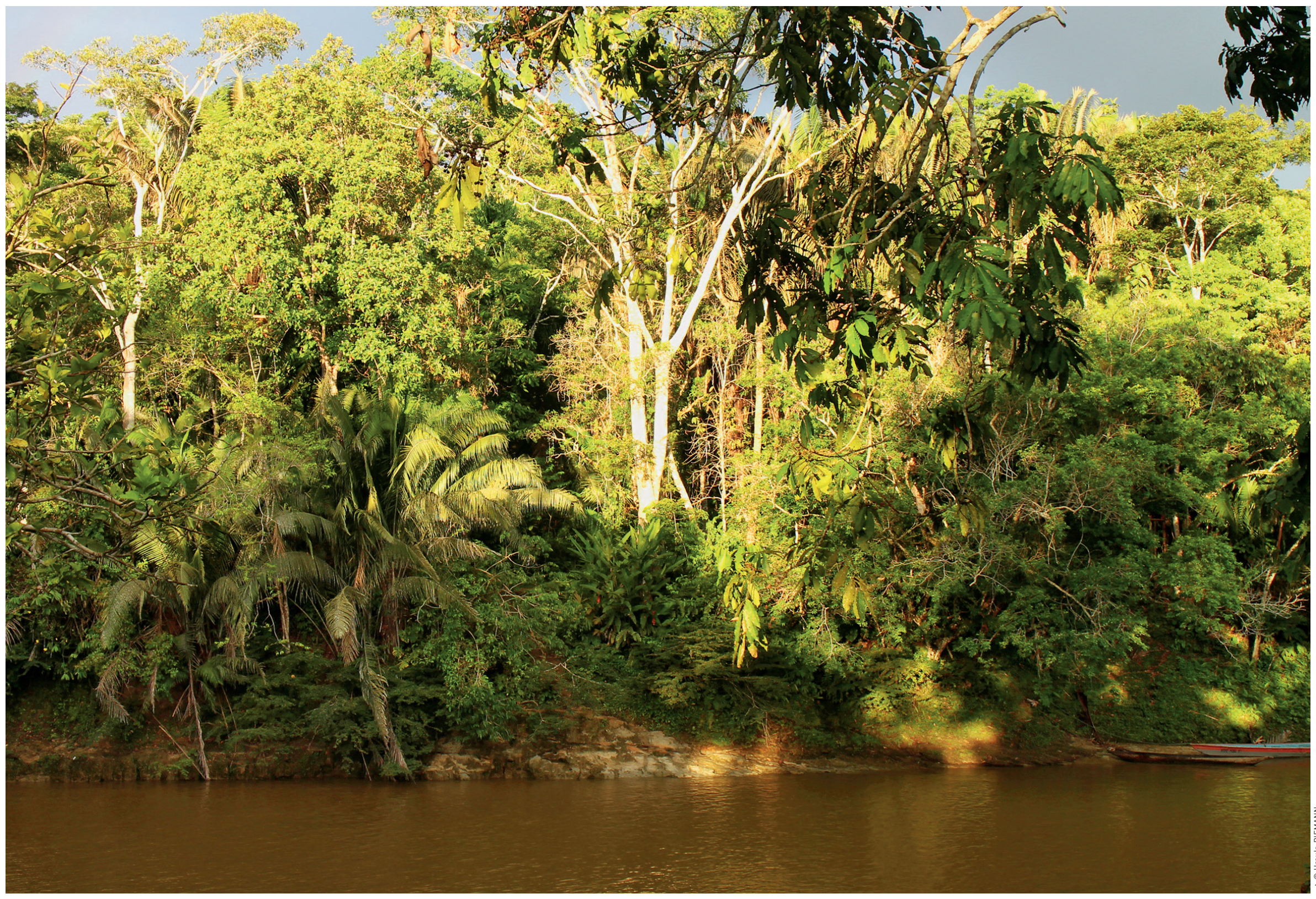


萨拉雅库地区鲜少允许外人探访, 而我 们有幸得到了一次难得的机会。站在厄瓜多 尔热带雨林中的邦波纳扎河畔, 土著活动家 弗朗戈・维特里告诉我们: “自工业革命开 始后的最近200年间, 世界将自然视为资源 的产出者, 却对其缺乏尊重。而我们必须明 白, 地球是有生命的, 这也是她能够给予我 们食物、对我们的所作所为做出反馈, 以及 懂得自我保护的原因。森林砍伐会导致海平 面上升, 这正是我们侵害生命森林时, 地球 做出的负面反馈。”这些目前正承受着由石 油开采需求所带来巨大压力的萨拉雅库克秋 亚部落, 从他们古老的宇宙学视角出发, 指 出了人类活动与地球反应之间的因果关系。 如果不是近年来像詹姆斯. 洛夫洛克这样的
气候学家和生态未来主义者为“盖亚假说” 提供了理论依据的话, 这些观点可能还会被 认为是虚无缥䍀的。吕事实上, 全球生态运 动对这种科学和政治观念的认同由来已久, 而厄瓜多尔一直是他们开展活动、为自然权 利奋斗的中心。

为了理解萨拉雅库这样承载着复杂关系 的地区, 厘清生命森林与海平面上升这两个 看似无关的事件背后的关联, 我们需要挖掘 更多的因果关系。若要揭示这个小型丛林村 落中的复杂关系, 非线性的叙述形式实为必 要: 受森林神灵庇护的森林生态、矿产开采 的全球性逻辑、创新型国际法的制度化、全 球环境运动、亚马逊热带雨林在地球气候中 扮演的角色, 此外还包括对影像散文以及当 hitps.//doi. org/10.15302/J-LAF-20180114 收稿时间 RECEIVED DATE / 2018-01-09 中图分类号 / J9, P9

文献标识码/
1. 得益于萨拉雅库土著居 民数世纪以来对于森 民林生态的格外关注和保 和保 位于厄瓜多尔亚马 逊地区的生命森林生长 得十分健壮, 且具有丰 富的生物多样性。

2. 加拿大阿尔伯塔省森科 尔采矿作业区鸟瞰图。 有毒的气体悬浮在这处 空旷的地区之上, 而这 里原来曾是郁郁葱葱的 里原来曾是
1. The Living Forest in the part of the Ecuadorian Amazon is exceptionally healthy and biodiverse thanks to the good care with which the indigenous people of Sarayaku have tended to the forest ecologies over centuries.
2. Aerial image of Suncor's mining operation in Alberta, Canada where toxic clouds hover over vast areas formerly covered by boreal forests.

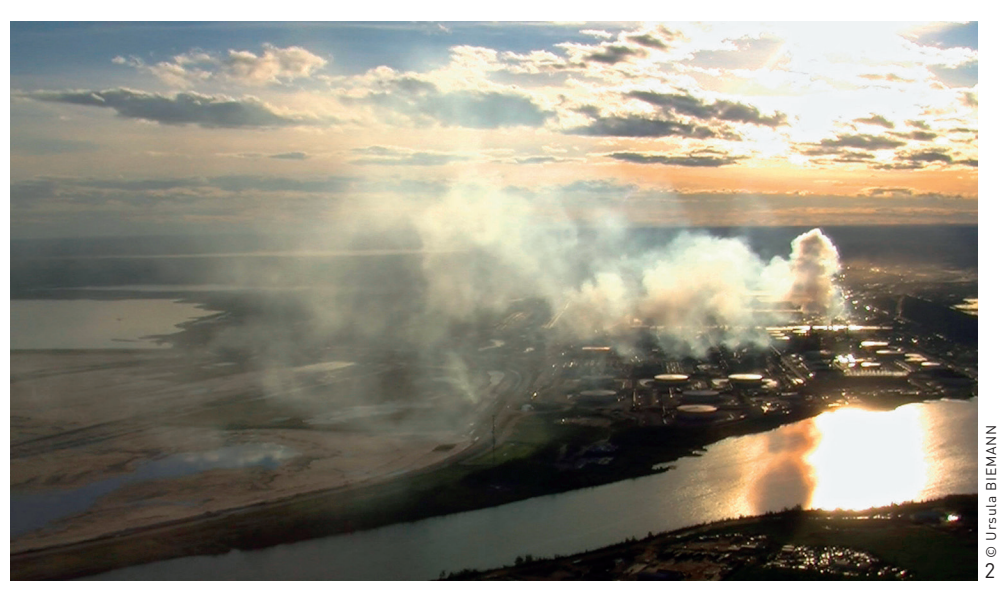

摘要

年来, 我的影片所关注的尺度已经从全球拓展到星球 范围。为探寻这一由非人类参与者扮演重要角色的新视角, 我实地考察的焦点也转向了偏远地区, 那里脆弱的生态系统 正承受着全球资源开采业带来的巨大压力。在本文中, 笔者 将通过《深度气候》( 2013) 和《森林法则》(2014) 两 部影片, 阐述如何以影像散文的形式来创作刧越其自身意义 的景观。在两部影片所展现的影像环境保护主义论述中, 自 然物质以及物理和气候过程不再作为叙述社会事件的戏剧化 背景一这些从幕后走到台前的主角, 承载着人与地球之间 脆弱、复杂、诗意而又极度实体化的关系。

关键词

影片; 当代叙事手法; 资源开采; 气候变化; 部落社会; 生态 危机

\section{ABstract}

In recent years, my videos have performed a shift from a global to a planetary scale. In pursuit of this new perspective where nonhuman actors begin to play an important role, my fieldwork has taken me to remote territories where fragile ecosystems have come under great pressure from the global resource extraction industry. In this article, I elucidate the two video works, Deep Weather (2013) and Forest Law (2014), to demonstrate how I use the video essay to create landscapes that are imbued with meaning beyond themselves. In the cinematic environmentalism these videos present and matter, physical and climatic processes no longer provide a dramatic backdrop for the narration of social events; they have moved to the fore to play the leading role, forming a world in which the human-Earth relationship is fragile, complicated, poetic, and intensely physical.

KEY WORDS

Video: Contemporary Narratives: Resource Extraction: Climate Change: Indigenous Communities; Ecological Crisis

译 孙一鹤 陆小球

TRANSLATED BY Robin SUN Xiaoxuan LU 

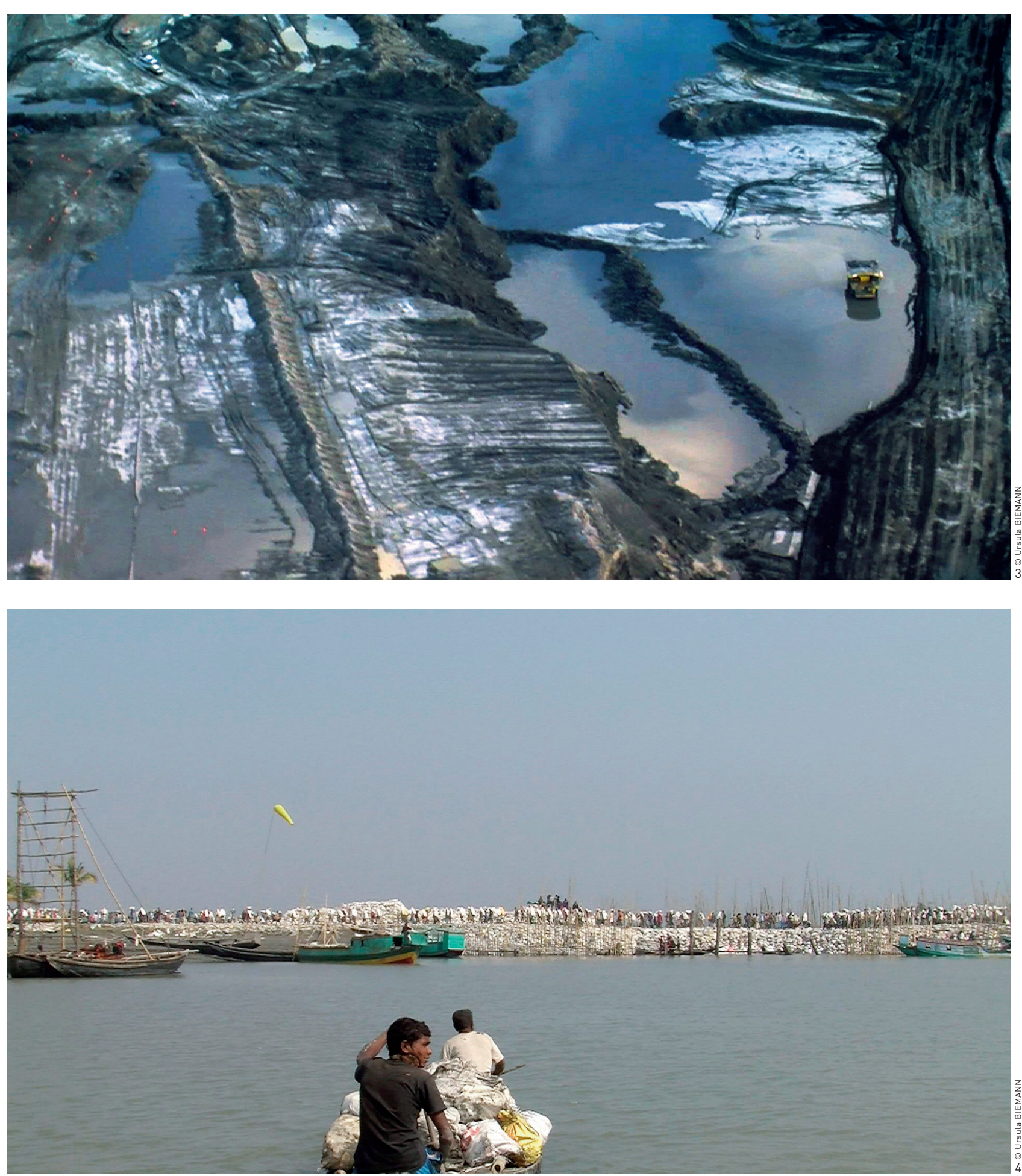

3. 在加拿大阿尔伯达省麦 克暮瑞堡地区进行的焦 油砂开采活动已经对北 方森林造成了灾难性的 破坏, 受灾森林面积几 乎相当于一个英格兰的 面积。
4. 在广阔的孟加拉国三角 洲地区找到适合建造堤 坝的场地是该地区人民 面场地是该地区人 到达任何一处堤坝待建 场地, 都需要花费两天 时间, 先驾车行驶一段
路途, 随后换乘快艇。 想要

3. Tar sand mining in
$\begin{array}{ll}\text { FortMcMurray, Alberta, } \\ \text { Canada, has destroyed } \\ \text { boreal forests the size }\end{array}$
$\begin{aligned} & \text { of England. } \\ & \text { binding embankment } \\ & \text { building sites in the } \\ & \text { is a major challenge. It } \\ & \text { took two days of travel } \\ & \text { by car and speed boat } \\ & \text { to reach one of them. }\end{aligned}$

代哲学的探讨。本文中, 我想详细阐述影像 散文这一表现形式如何协助表述分层的空间 意义。通过尝试将不同的标示和层面汇集, 一个想象的空间由此被创造出来，犹如一个 驱动不同的思考生发并相互碰撞的理论平 台。在每一部作品中, 影像散文制作者都会 设置这样的空间。我们可以将其视为一块虚 构的地形, 发生在各个偏远地区的所有思想 和事件都会受到这一空间秩序的引导。

我的影像作品深受20世纪80年代初的 后结构主义电影实践的启发，即所谓的“影 像散文”。这种电影以试验性、自我反思式 和从主观视角出发的形式描述世界, 介于纪 录片、视频艺术和理论思考之间。这种理论 建构的视觉化手段反复探索了形象塑造的真 正作用和促生意义的欲望强度。这种电影对 单纯收集信息和事实并不感兴趣, 因为影片 制作人并不相信这些可以代表真相。他们更 希望反映世界和社会的秩序，并常常将物质 放置在一个与其存在关联的特定地点来实现 这一点。换句话说，影像散文制作者的惯用 手法不是记录现实, 而是对错综复杂的关系 进行梳理; 影像散文则旨在在全球化背景下 捕捉那些更为抽象的、无形的社会文化转型 过程。

在20世纪90年代末的早期实践中, 我 就已经构建了自己的影像散文风格, 即通 过观察高速全球化世界中人口的流动情况， 重点关注新兴全球生产区中的女性劳动力和 非法移民格局。近年来, 我的兴趣开始转向 紧张的人地关系, 即从全球范围拓展到整个 星球范围。为探寻这一由非人类参与者扮演 重要角色的新视角, 我实地考察的焦点也转 向了偏远地区, 那里脆弱的生态系统正承受 着全球资源开采业带来的巨大压力。在本 文中, 我将通过《深度气候》（2013）和 《森林法则》(2014) 两部影片阐述如何 以影像散文的形式创作超越其自身意义的景 观。在两部影片所展现的影像环境保护主义 论述中, 自然物质以及物理和气候过程不再 作为叙述社会事件的戏剧化背景一它们从 幕后走到台前, 成为影片的主角。这一重要 的“图底关系”的转变引出了一个亟待解决 

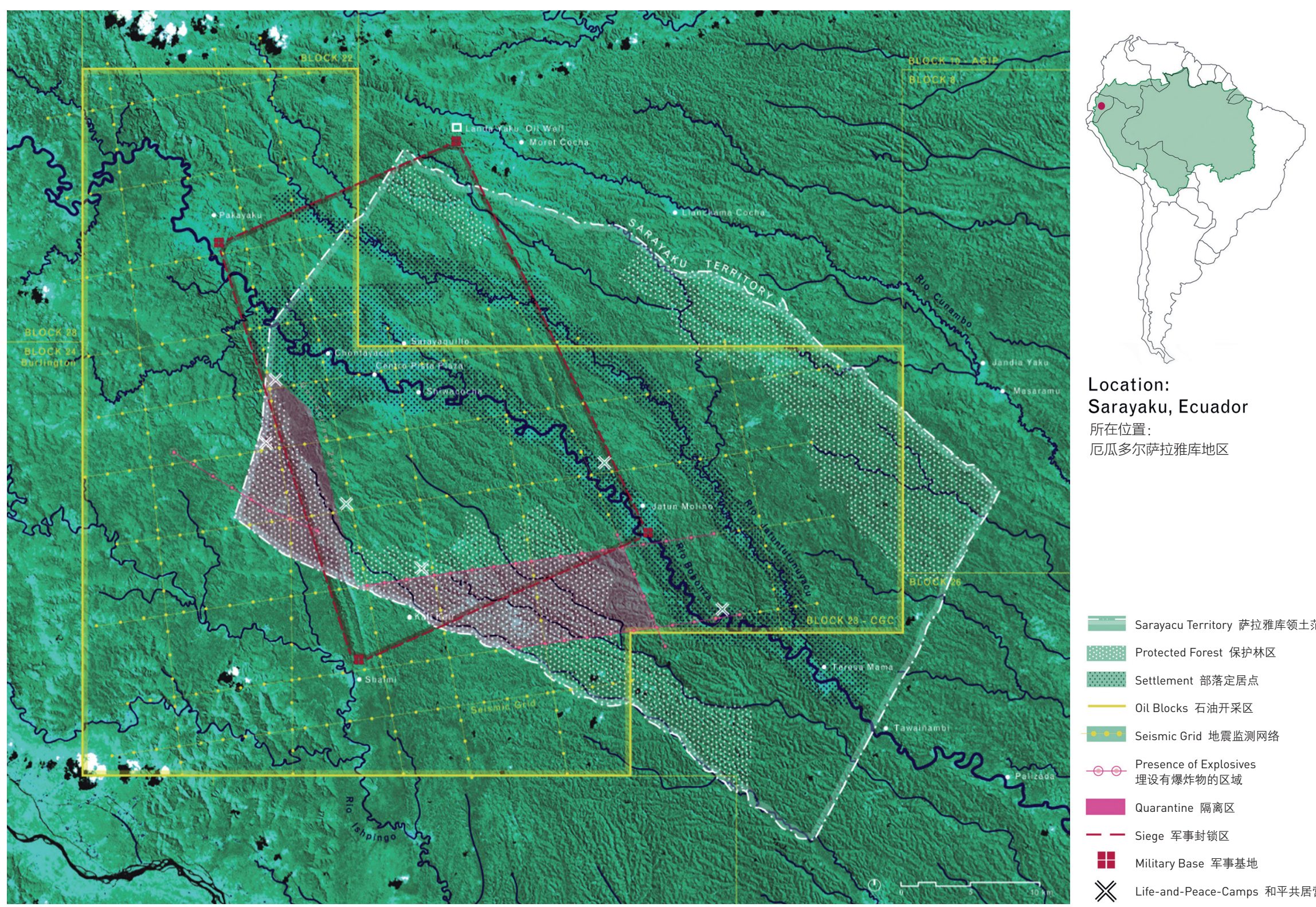

\section{Location:}

Sarayaku, Ecuador

所在位置:

厄瓜多尔萨拉雅库地区

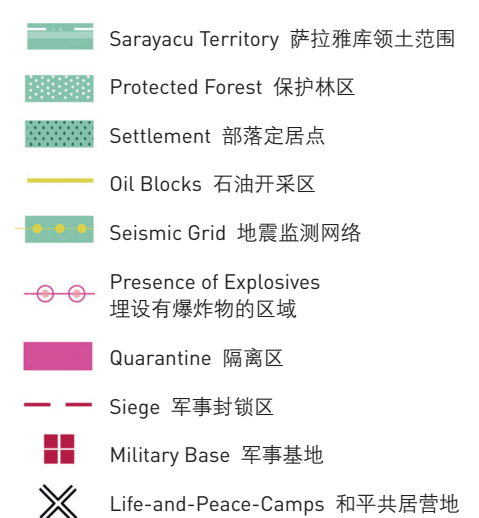

5. 由萨拉雅库居民集体所 有的林区与厄瓜多尔政 府新近授权的由全球多 个石油公司共同运营的 法律计突。
5. The collectively owned forest territory of the people of Sarayaku juridically conflicts with the recently introduced oil blocks licensed by the state of Ecuador to global oil corporations.
的问题: 如何重新构建艺术工作者与非人类 环境之间的关系? 借助影片制作, 我主要通 过影像实践来探查我们对世界造成的直接影 响。从这个意义上说, 我认为我的影片就好 像是各种不同的地形 ${ }^{[2]}$, 承载着人与地球之间 脆弱、复杂、诗意而又极度实体化的关系。

\section{《深度气候》( 2013$)$}

简短的单频影像散文《深度气候》同时
呈现了两个相距遥远却通过大气化学过程相 互联系的场景: 其中一个场景是对加拿大北 部阿尔伯塔焦油砂中矿物燃料的不断挖掘, 另一个场景则展现了位于世界另一端的孟加 拉国沿海社区所采取的保护措施。影片开头 以直升机视角俯瞰广阔的加拿大北方森林中 巨大的焦油砂露天开采区, 那里形成了一个 具有润滑油质感的深色地质带。有毒废弃物 被储存在开阔的尾矿湖中, 逐渐吞噬大面积 的土地, 直到新近被古老的云杉森林和松软 
的湿土所覆盖。由于开采边界不断向原始地 区腹地（原住民部落的狩猎场）入侵，包括 人类在内的数百种物种的生存和迁徙空间被 彻底改变。

《深度气候》的画外音中融入了诗意的 科幻小说叙事方式。这个声音与航拍录像相 互配合在风中低语, 如同从加拿大延伸到孟 加拉国的大气的化身。它们共同激活了一个 超越当前物理和政治实体的时空。《深度气 候》不露痕迹地将自身置于生物圈之中, 通 过抵达黑色地球的内部和触及百公里高处的 大气层, 深化对这些地形的认知, 即矿物燃 料的开采不仅仅是一个地缘政治考量, 也是 一种生物地球事实。

《深度气候》配音节录:

“野生动物早已逃离,

猎区内空空如也,

长者们呼唤神灵,

年轻人说唱饶舌,

被酸化的风嘶嘶作响。

他们都在感叹进化速度还远远不够，

改变请快些来临! ”

《深度气候》的第二部分则转向了孟加 拉国。喜马拉雅冰原融化、地球海平面上升
和极端天气事件造成的后果在很大程度上决 定了孟加拉国，特别是其恒河三角洲地区的 民生状况。该影片记录了孟加拉国为应对全 球变暖问题所采取的诸项适应性措施之一: 发动社区的巨大力量建造土堤。造成影响和 受到影响的两处地点分处地球的两端。在加 拿大，重质燃料过度开采、大量资金投入、 大型机械做工，以及随着时间推移持续加深 的纵向开采深度; 在孟加拉国, 三角洲社区 被淹没, 体力劳动者数量庞大, 海平面上升 涉及到的横向面积不断扩张。

\section{《森林法则》 ( 2014 )}

《森林法则》基于在厄瓜多尔热带雨林 中的石油开采区进行的实地考察, 由我和巴 西建筑师保罗 ·塔瓦雷斯共同创作。我们在 厄瓜多尔的研究轨迹跨越了多条在森林中同 时存在的叙述主线。这些叙述基于考察中遇 到的部落活动家和律师, 他们致力于构想和 争取保障包括非人类环境在内的法律框架。 在这些人中, 克秋亚族法官尼娜 - 帕卡里 对于制定新的非人环境权利法律起到了至关 重要的作用。在与萨满医生胡里奥·缇维莱
姆会面时, 我们钦佩于他渊博的森林药学知 识。居住在低地深处的萨拉雅库人民领袖何 塞 · 瓜林加让我们明白他们对生命森林及其 保护者的理念构想。最后, 我们与厄瓜多尔 人类学家爱德华多. 科恩进行了对话。在他 的启蒙性著作《森林如何思考》中, 科恩探 讨了人类如何在与多种植物、动物和微生物 相处的过程中形成自己的族系并不断进化， 同时进一步将这一哲学化和符号化的框架扩 大, 以将更多其他生物纳入具备思考能力的 生物清单之中。

在《森林法则》中, 这些法律、科学、 符号学和宇宙学叙述形式共同组成了认识森 林生态的高密度结构。曾作为证据在美洲人 权法院听证会上予以出示的萨拉雅库卫星地 图, 通过将大地对于土著居民的重要意义与 当前的地质开发方案相叠加, 揭示了萨拉雅 库地区管辖权的深层冲突。从微观到宏观层 面, 《森林法则》展示了人类对于现实的各 种想象。首先, 这个项目再次引出了那些不 断被全球资本主义主流言论诟病的复杂的景 观历史。此外, 通过将水体、森林、部落族 群、景观、气候以及石油和铜的地缘政治之 间的紧密关系精巧呈现, 这一影像散文谱写

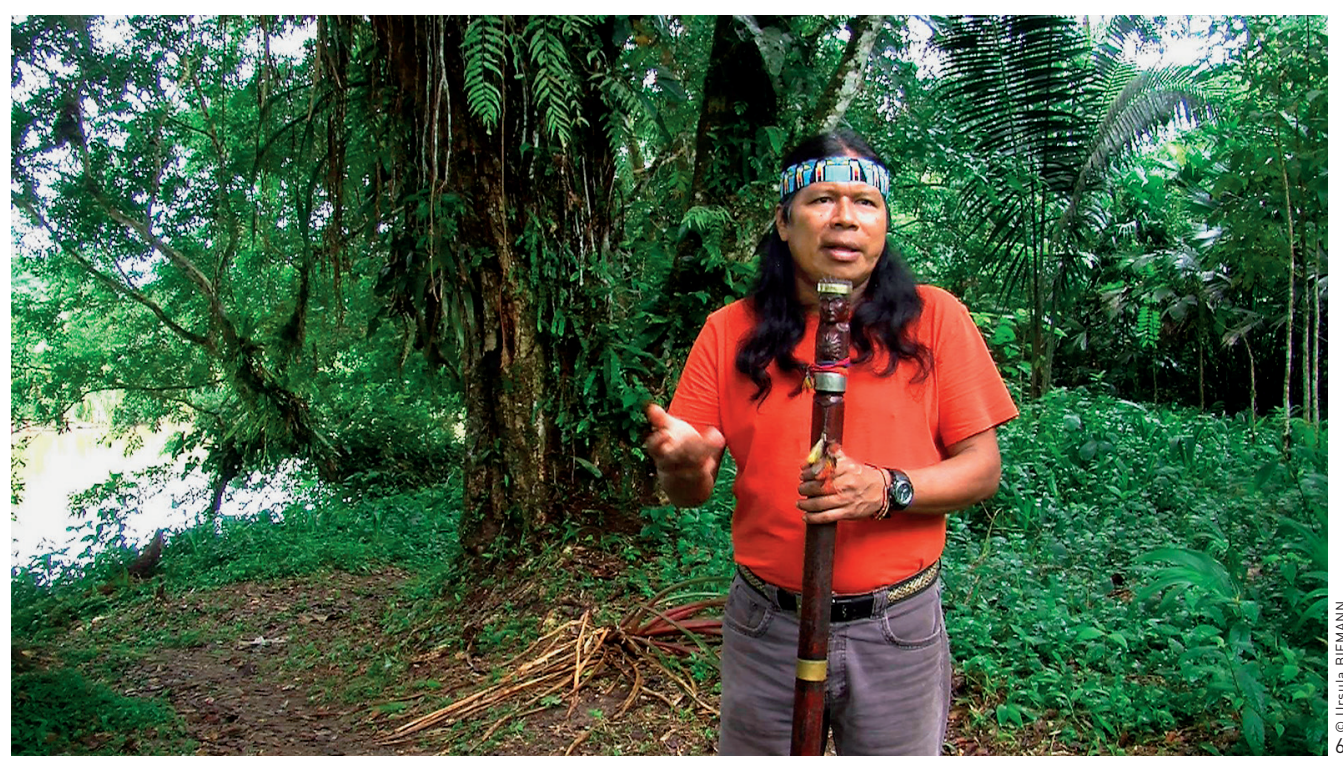

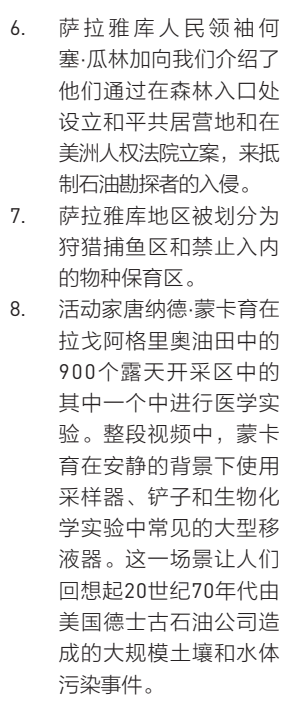

萨拉雅库人民领袖何 塞·瓜林加向我们介绍了 他们通过在森林入口处 设立和平共居营地和在 美洲人权法院立案, 来抵 制石油勘探者的入侵。

7. 萨拉雅库地区被划分为 狩猎捕鱼区和禁止入内 的物种保育区。

8. 活动家揵纳德蒙卡充 拉戈阿格里奥油田中的 900个露天开采区中的 其中一个中进行医学实 验。整段视频中, 蒙卡 育在安静的背景下使用 采样器、铲子和生物化 采样器、铲子和生物化 子学实验中常见的大型移 液器。这一场景让人们 回想起20世纪70年代由 美国德士古石油公司造 成的大规模土壤和水体 污染事件。

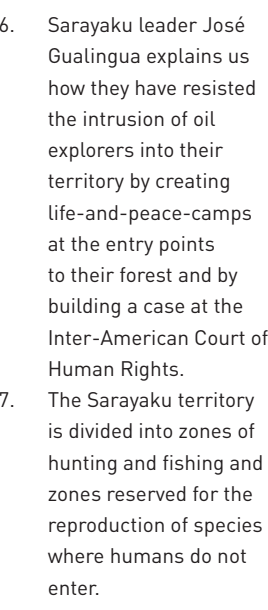

8. Activist Donald Moncayo performs a forensic tes in one of the 900 openoil fields. His mute performance handling the samplers, shovels, and giant pipettes of the eco-chemists throughout the video as of a large-scale contamination of soils Texaco in the 1970s. 

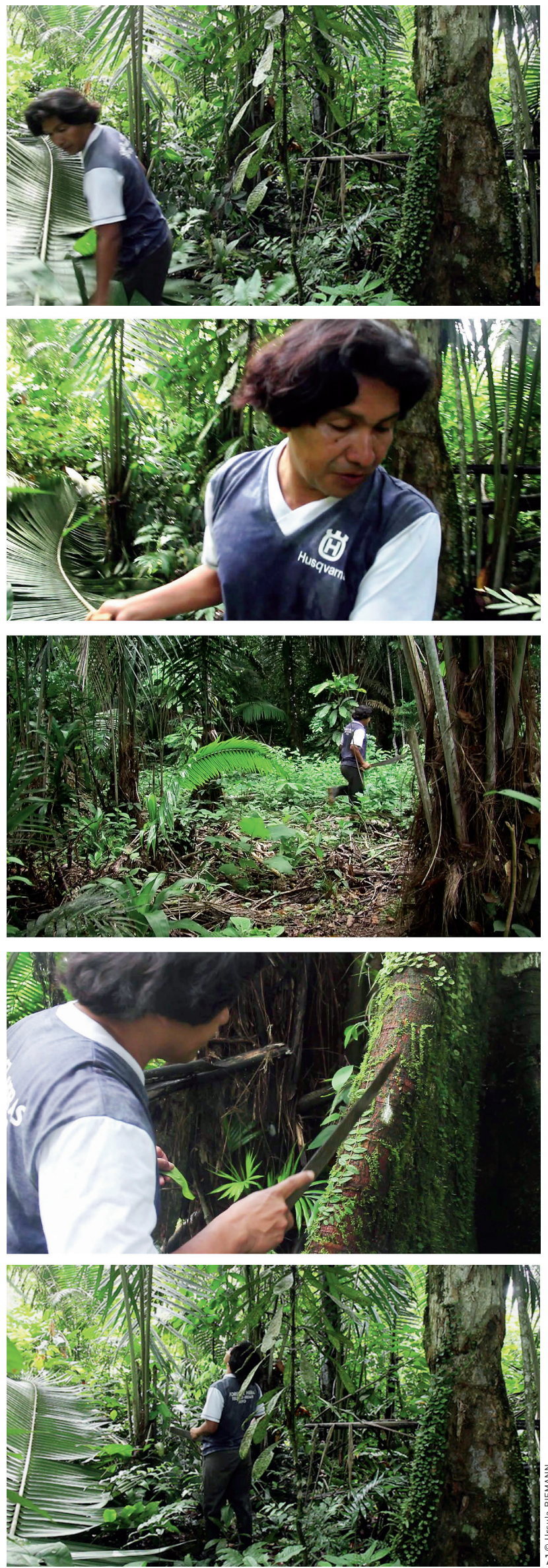

出别样的大地叙事。

该项目关注那些超越了人本中心视角的 实践，其中不同的叙述层展现了观察自然和 生命形式的当地视角以及作为 “法律主体” 的当地生态。影片还在我们目前完全基于 财产权的普遍法律结构和大规模森林破坏及 物种灭绝间建立起直接联系。随着镜头与这 片阴暗、雾气朦胧的雨林之间的距离逐渐拉 远，影片开头将地球描绘为以其表面多年演 变而成的生态系统维持自身新陈代谢的鲜活 星球。如若气温上升 $4^{\circ} \mathrm{C}$, 亚马逊生态系统 将变为干旱的灌丛之地, 这个重要的冷却系 统一旦停止运行, 地球将日益炎热和干旱, 人类粮食生产用地也将不断缩减。这种叙事 结构并非意在发出生态预警，而旨在强调雨 林偏远角落中发生的一切对于整个世界而言 都至关重要。

我们很容易获取大量关于气候和环境的 真实信息和科学数据, 但仅凭理性思考并不 足以使我们理解当前地球环境变化的程度。 为此, 以各种不同的美学交流形式强化认知 空间十分必要。当转向全球变暖这一议题 时, 我认为影片制作的主要目的并不仅仅 是陈述新的事实, 更是在观众的想象中创
造一个新的场所, 以承载那些影响着远至 孟加拉三角洲最边缘的社区、广至整个星球 生命体的错综复杂的条件。我们需要能够同 时关注超越地域限制的极小或极大实体的 更具包容性的想象力一一至昆虫、大至 全球变暖；小至瞬时的黄金汇率，大至自 动化操作的世界金融市场。这要求我们施 展自身的想象力, 以实现一种更具展望性的 模式。LAF

注释

影片《森林法则》将在于2018年11月至2019年3月期间在第十二 届上海双年展上公映（详见http://www.shanghaibiennale.org/ en/page/detail/049do.html ), 相关展览“让我们聊聊气候 变化” 将于2018年6 - 8月在广州时代美术馆展出 (详见htt $\mathrm{p}: / /$ en.timesmuseum.org/)。了解作者的更多相关项目, 请登录 en.timesmuseum.org//)

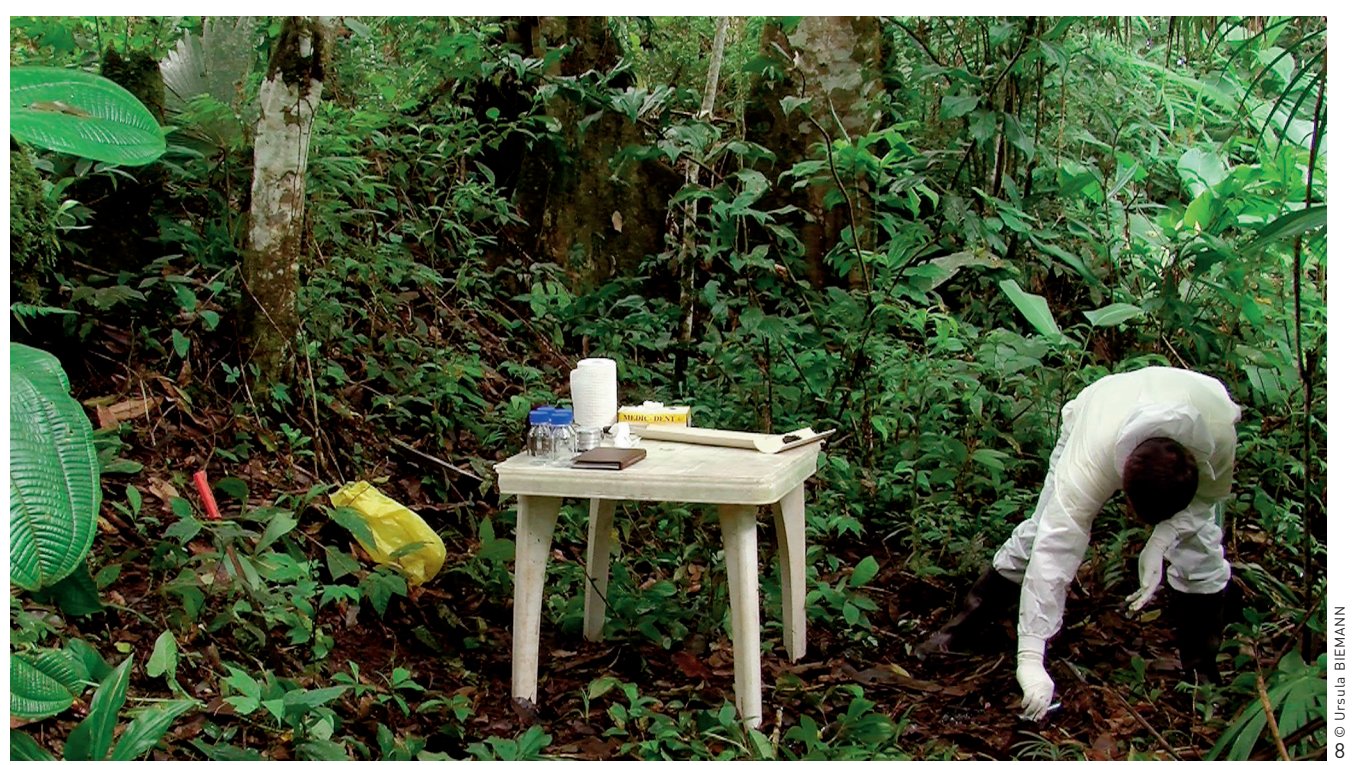


Standing on the banks of the Bobonaza River in the Ecuadorian rainforest, indigenous activist Franco Viteri tells us during a rarely allowed visit to Sarayaku: "In the last two hundred years of industrialized life, the world viewed nature as a provider of resources, without respecting it. But we have to understand that Earth is alive, that is why she gives us food, that is why she reacts, that is why she defends herself. When you see the sea level rising, it is because of deforestation. When we are violating the Living Forest, Earth will react negatively." In their age-old cosmology, the indigenous Kichwa Nation of Sarayaku, currently under tremendous pressure from oil extractive desires, draws a causal relationship between human action and terrestrial response. These ideas would be termed mythical, if it was not for climate scientists and ecological futurists like James Lovelock who have provided the theoretical arguments for the Gaia hypothesis in recent years. ${ }^{[1]}$ The global ecological movement has, of course, shared this scientific and political paradigm for much longer, and Ecuador has been the epicenter of their action and struggles for the rights of nature.

To engage with the extraordinary thickness of a place like Sarayaku, and fill in the blanks between the end points of the Living Forest and sea-level rise, many more causal connections need to be made along the way. A non-linear narrative form is required to unravel the complexity of relations converging in this little forest village: The forest ecology protected by forest spirits, the global logic of mineral extraction, the institutionalization of innovative international laws, the global environmental movement, the role of the Amazonian rainforest in planetary climate, as well as essayist video-making, and contemporary philosophy. In this article, I would like to elaborate on how the essayist video form has been useful in narrating the layered signification of this space. The attempt to draw the different registers and layers together leads inevitably to the creation of an imaginary space, a sort of theoretical platform on which these reflections can take place and be in dialogue with each other. In every work, essayists install this kind of space. We can think of it as an imaginary topography, on which all kinds of thoughts and events taking place in various remote places experience a spatial order.

My video works are deeply indebted to a post-structuralist cinematic practice emerging in the early 1980s, defined as film essays. It is an experimental, self-reflexive, and subjective form of narrating the world that lies somewhere between documentary film, video art, and theoretical thought. It is a visual form of theory-building that constantly reconsiders the very act of imagemaking and the desire to produce meaning. The mere gathering of information and facts is hardly of interest, for the essayist does not believe in the representability of truth. The essayist intention lies much rather in a reflection on the world and the social order, and he or she does so by arranging the material into a particular field of connections. In other words, the essayist approach is not about documenting realities but about organizing complexities. This is one of the reasons why the essay has been so good at capturing the more abstract, intangible processes of social and cultural transitions in the globalized context.

I have developed my own recipe for the video essay in my earlier practice in the late 1990s, when making observations about the movements of people in a rapidly globalizing world, placing the focus on female labor in the emerging global production zones and on illicit migration networks. In recent years, my interest has turned to the strained relationship between humans and Earth. I see this to be a move from the global to a planetary scale. In pursuit of this new perspective where nonhuman actors begin
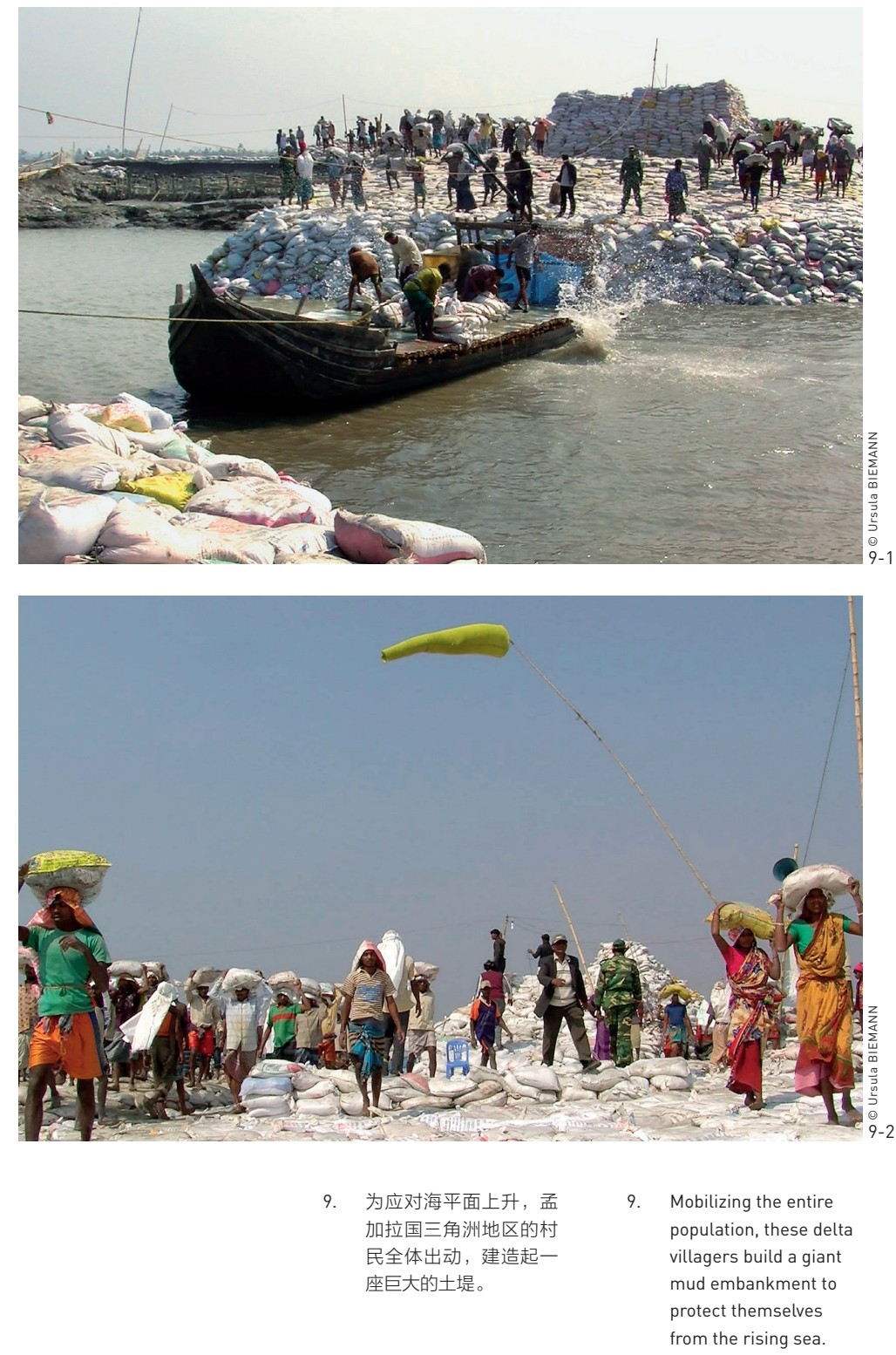
to play an important role, my fieldwork has taken me to remote territories where fragile ecosystems have come under great pressure from the global resource extraction industry. In the following paragraphs, I will elucidate the two video works, Deep Weather (2013) and Forest Law (2014), to demonstrate how I use the video essay to create landscapes that are imbued with meaning beyond themselves. In the cinematic environmentalism they present and matter, physical and climatic processes no longer just provide a dramatic backdrop for the narration of social events; they have moved to the fore to play the leading role. In this major figure-ground shift, one particularly urgent question has emerged: how to reconfigure the relationship between the artist-author and the nonhuman world? In filmmaking, this largely amounts to an inquiry into our direct implication in the making of this world through imaging practices. In this sense, I would like to think of my videos as geomorphic ${ }^{[2]}$. They form a world in which the human-Earth relationship is fragile, complicated, poetic, and intensely physical.

\section{Deep Weather (2013)}

Deep Weather is a short, single-channel video essay, drawing the connection between the relentless unearthing of fossil fuels in the Alberta tar sands of Northern Canada and the protective measures undertaken by Bangladeshi communities on the other side of the world - two remote and simultaneously occurring scenes connected through their atmospheric chemistry. The opening shot of the film looks down from a helicopter on the huge open-pit extraction zone of the tar sands in the midst of the vast Canadian boreal forest, establishing a zone of dark, lubricant geology. The toxic waste is stored in open tailing lakes that spread over large areas which until recently were covered by ancient spruce forests and spongy wet soil. Pushing extraction frontiers far into the pristine territories, the hunting grounds of First Nations communities, drastically changes the living and migrating space of hundreds of species, including humans.

The voice over in Deep Weather is infused of a poetic science-fictional narrative. The voice, whispered into wind like a personification of the atmosphere itself that reaches from Canada to Bangladesh, resonates with the aerial video footage.

Together they activate a time-space beyond the immediate physical and political reality. Implicitly locating itself in the biosphere,

Deep Weather thickens the understanding of these geographies by reaching into the interior of the black Earth and extending a hundred miles into the atmosphere, as fossil fuel extraction is not merely a geopolitical concern but also a bio-planetary reality.

Excerpt from the whispered voice over in Deep Weather:

\footnotetext{
"The wildlife has retreated;

The traplines are empty;

The elders call the spirits;

The young ones sing rap songs;

And the acid wind is hissing.

Evolution is not fast enough. Mutate!"
}

The second part of Deep Weather turns to Bangladesh, where the consequences of melting Himalayan ice fields, rising planetary sea levels, and extreme weather events largely define living conditions, particularly in the Delta. The video documents one of the adaptations Bangladeshi are making that is particularly emblematic for an age of global warming: The tremendous community effort made to build protective mud embankments. There is a planetary distance between the sites of cause and effect. In Canada, the aggressive mining of heavy fuel, major investment, large machinery, and the vertical desire of extraction into the depths of time; in Bangladesh, the drowning of delta communities, the manual labor of millions, and the submerged expansion into the horizontality of the rising oceans. 


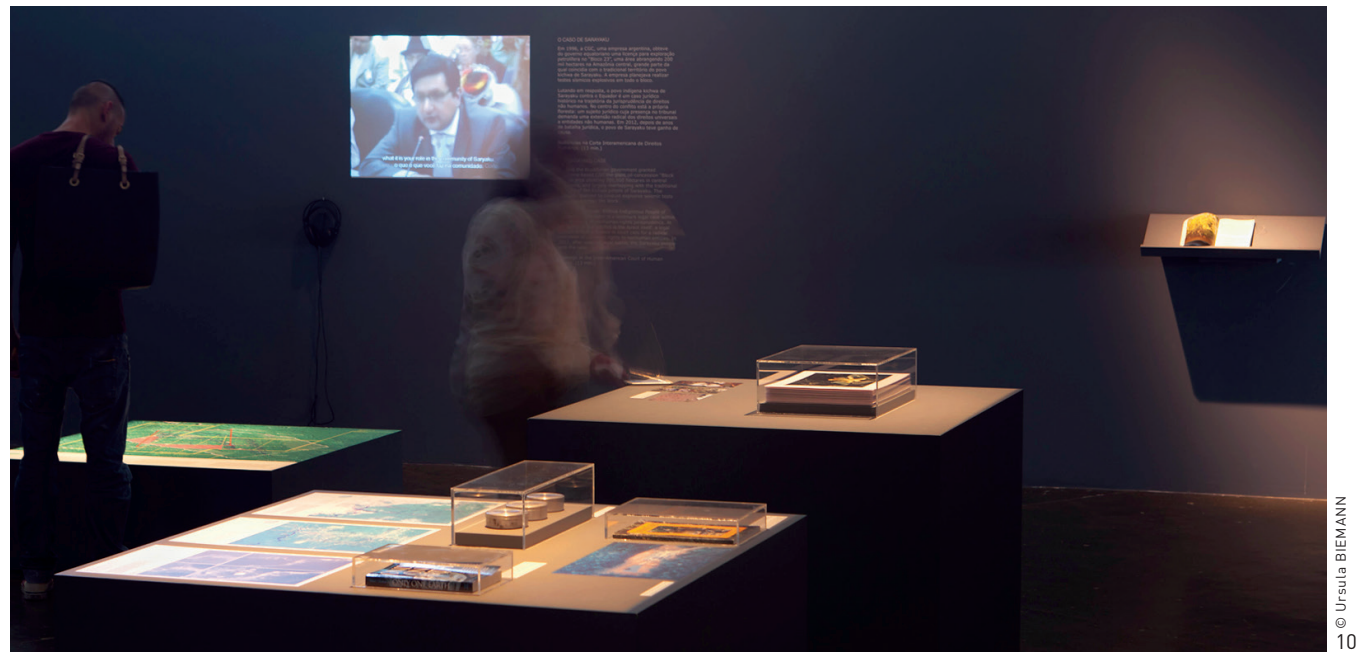

\section{Forest Law (2014)}

Collaboratively produced with Brazilian architect Paulo Tavares, Forest Law is based on a fieldtrip undertaken on the oil-andmining frontier of the Ecuadorian rainforest. To begin with, our research trajectory in Ecuador crossed diverse narrative threads that run together in the forest. We sought out encounters with indigenous activists and lawyers who conceive of, and struggle for, a legal framework that includes nonhumans. Among them, Nina Pacari, a Kitchwa constitutional justice, has been crucial in forging the new laws of nonhuman rights. In an encounter with profound pharmaceutical knowledge of the shaman Julio Tiwiram, we learned about his forest. José Gualinga, leader of the people of Sarayaku in the depths of the lowland, gave us insight into their concept of the Living Forest and its protectors. And finally we entered in dialogue with Ecuadorian anthropologist Eduardo Kohn, who explores, in his illuminating book How Forests

Think, how the human has been formed and transformed amid encounters with multiple species of plants, animals, and microorganisms. In doing so, Kohn expands philosophical and semiotic frameworks to include other living beings in the list of those capable of thinking

In Forest Law, these legal, scientific, semiotic, and cosmological narratives converge to form a dense epistemological fabric of the sylvan ecology. In the design of the Sarayaku satellite map, also used as evidence in court during the hearings at the Inter-American Court of Human Rights, indigenous signification of the land and current geological exploitation schemes merge, exposing the deeply conflicted jurisdiction of the Sarayaku territory.

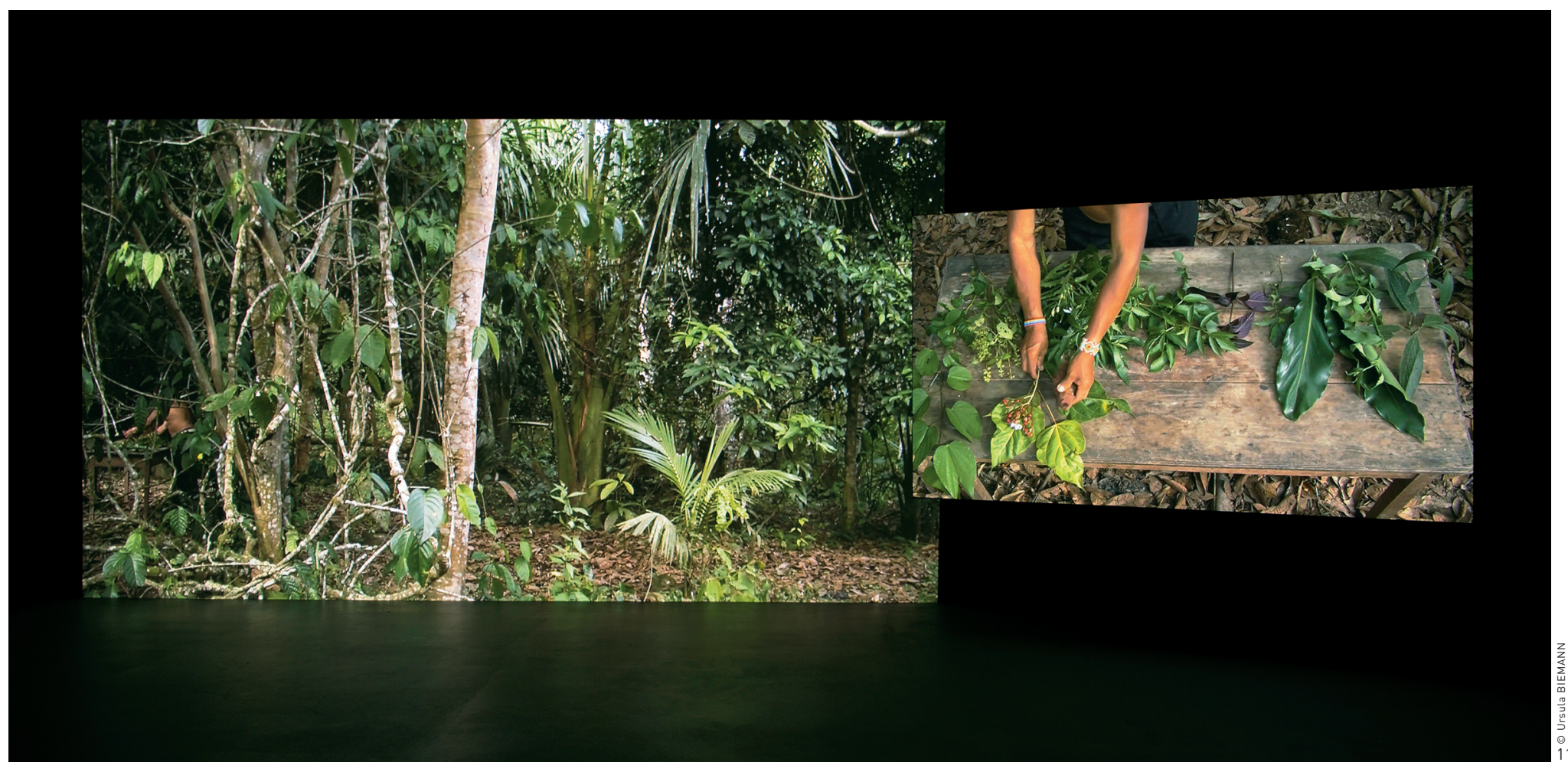


10. 在圣保罗双年展 (2016) 上展示的《冧 林法则》影片及相关地 林法则》影片及相关地 图和文件, 还包括了展 现人权法庭审理过程中 萨拉雅库居民所述观点 的录像。

11. 由立体声音和视觉系统 同步展示的两个视频, 其展示了可供各个空 间维度的生物体栖居的 间维度的生物体栖居的 景观, 以及萨满医生 胡里奥. 缇维莱姆的森 林药房

12. 作为 “森林法则” 项目 一部分的双语图书《森 林法则》展示了亚马逊 西部生命森林边界景观 的各种景象。
10. Assemblage of the maps and documents generated for the Forest gaw instaltion in the Biennal of Sao Paulo (2016) including the video of the hearings of the Sarayaku people at the Court of Human Rights.

11. The two synchronized videos, in their stereo optic, expose stereo optic, expose a landscape that is populated by all kinds of sentient beings, who inhabit different dimensions of reality, and Julio Tiwiram in his forest pharmacy.

12. As part of the Forest Law project, the bilingual artist book Forest Law - Selv Jurídica navigates across a frontier landscape - the Living Forests of western Amazonia.

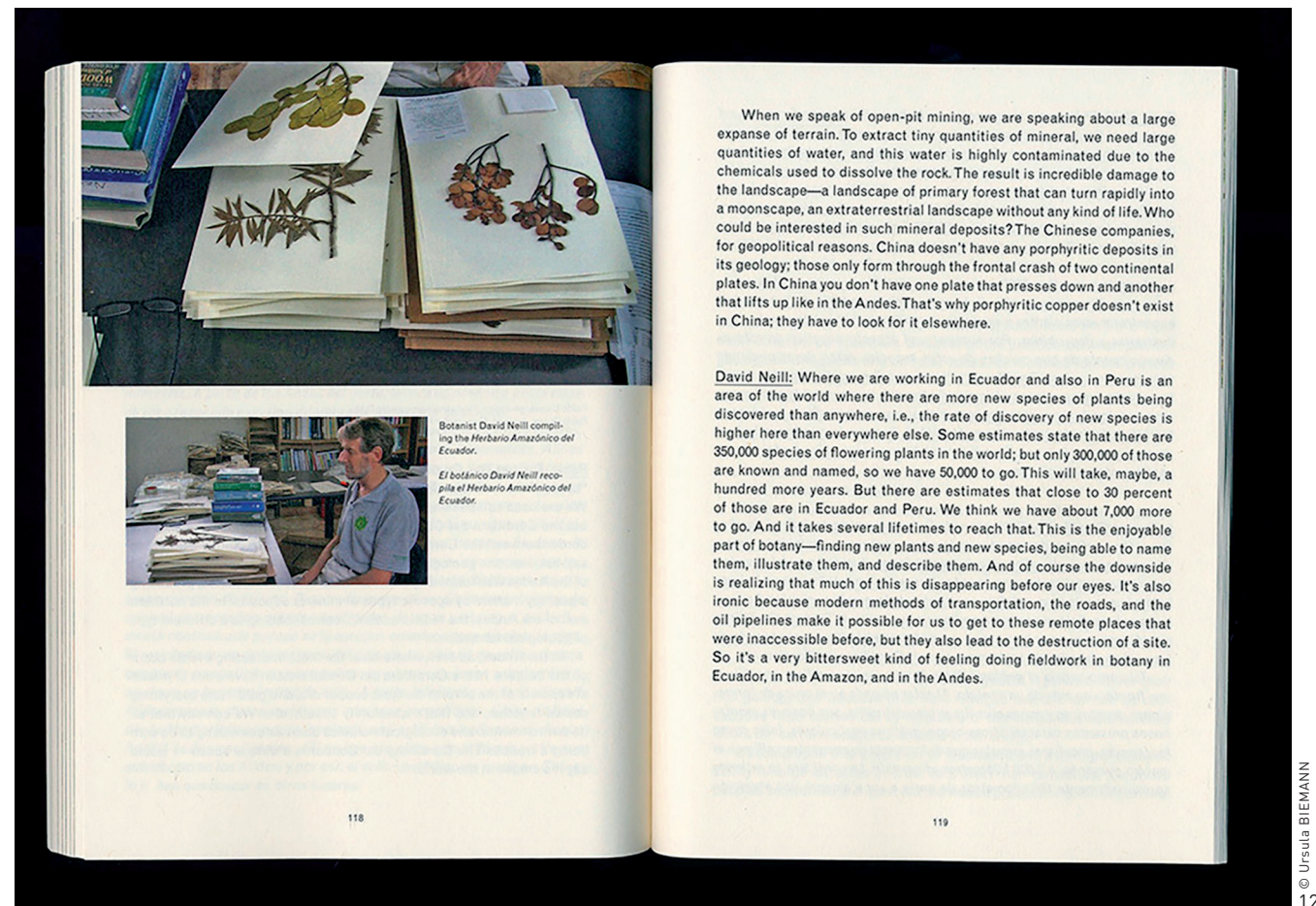

misty rain forest, the video prologue evokes the Earth as a living planet whose surface has evolved into ecosystems that keep her metabolism alive. With a $4^{\circ} \mathrm{C}$ rise in temperature, the Amazon ecosystem would turn into dry scrub, an essential cooling system would then be shut down, and the planet would turn increasingly hot and dry, with ever shrinking land left for human food production. Rather than an eco-apocalyptic vision, this narrative construction suggests that what unfolds in this remote corner of the rainforest is of worldly importance.

It is fairly easy to access vast amounts of factual information and scientific data about the climate and environment, but rational thinking alone cannot make us understand the magnitude of change we are in. For this, different forms of aesthetic communication addressing the imaginary will be necessary. When it comes to global warming, I see the main purpose in video making to be not primarily the presentation of new facts, but the creation of a new place in the viewer's imaginary that can accommodate entangled conditions which affect the most marginal communities in the Bengal Delta as much as life on the planet as a whole. What is needed are more inclusive models of imagination that simultaneously pay attention to the very tiny and very large, non-local entities, like insects and global warming; or minute gold deposits and automated world financial markets. We are asked to stretch our imaginary and enter a more speculative mode. LAF

NOTE

Forest Law will be shown at the 12th edition of the Shangha Biennale from November 2018 to March 2019 (http://www. shanghaibiennale.org/en/page/detail/049do.html), as well as "Let Guangzhou from June to August 2018 (http://en.timesmuseum. org/l. For more information about the author's work, please visit http://www.geobodies.org/.

\section{REFERENCES}

[1] Lovelock, J. (2007). The Revenge of Gaia. London: Penguin.

[2] Ivakhiv, A. J. (2013). Ecologies of the Moving Image. Waterloo: Wilfrid Laurier University Press. us talk about the Weather" exhibition at the Times Museum in 